\title{
Vibrio damsela from wounds in bottlenose dolphins Tursiops truncatus
}

\author{
R. S. Fujioka ${ }^{1}$, S. B. Greco ${ }^{1}$, M. B. Cates $^{2}$, J. P. Schroeder ${ }^{3}$ \\ ${ }^{1}$ Water Resources Research Center and Department of Microbiology, University of Hawaii, Honolulu, Hawaii 96822, USA \\ ${ }^{2}$ Academy of Health Sciences, Fort Sam Houston, Texas 77225, USA \\ ${ }^{3}$ Naval Ocean Systems Center Hawaii Laboratory, Kailua, Hawaii 96734, USA
}

\begin{abstract}
Some of the bottlenose dolphins kept in coastal sea pens in Hawaii developed slowhealing wounds and were treated with trimethoprim/sulfadiazine. Vibrio bacteria recovered from healthy skin and wounds of dolphins as well as the sea pen water were identified using the 54 test system of West \& Colwell. The popular 26 test A.PI-20 E system was of limited value in identifying many vibrios recovered from environmental sources. Predominant vibrios recovered from sea pen water and from healthy dolphin skin were Vibrio alginolyticus and $V$. marinus, respectively. These vibrios remained sensitive to trimethoprim and sulfadiazine. The predominant vibrio recovered from dolphin wounds was $V$. damsela which developed resistance to the 2 antimicrobial agents used to treat the dolphins. This resistance was taken as additional evidence that $V$. damsela was multiplying at the wound site. $V$. damsela is a known pathogen of fish and humans and is believed to be the primary bacterium causing wound infections in dolphins.
\end{abstract}

\section{INTRODUCTION}

Bottlenose dolphins Tursiops truncatus are kept in coastal sea pens and trained by Navy personnel at the Naval Ocean Systems Center (NOSC) in Kaneohe Bay, Hawaii. The health of these marine mammals must be maintained to ensure their high level of performance. These dolphins occasionally acquire external wounds which normally heal within $7 \mathrm{~d}$ (Bruce-Allen \& Geraci 1985). However, some dolphins experience slow-healing ( $>14 \mathrm{~d}$ ) wounds that clinically appear to be due to bacterial infections. Researchers in the field of marine mammal care such as Geraci (1981), Howard et al. (1983) and Simpson \& Cornell (1983) have reported that infectious diseases constitute the greatest hazard to the health of captive marine mammals. Despite this, the etiological agents responsible for causing wound infections in marine mammals have not been identified.

We reasoned that the most likely etiological agent of dolphin wound infections would be vibrio bacteria since several vibrio species had been documented as infecting and causing diseases in poikilothermic animals including fish (Elston et al. 1981), oysters (Di Salvo et al. 1978), crustaceans (Lightner 1977), and eels (Tison et al. 1982), as well as in mammals exposed to seawater (Rubin \& Tilton 1975, Blake et al. 1980). Moreover, vibrios are important marine bacteria and their concentrations are known to be highest in coastal waters, the natural environment of dolphins at NOSC. One result is that recovery of vibrio bacteria from body surfaces of dolphins may only indicate the presence of residual seawater. On the other hand, bacteria establishing an infection adhere specifically to the cells where they multiply (Mertz et al. 1987). Thus, careful sampling techniques and identification methods must be used to determine the pathogenic potential and site specificity of vibrios recovered from skin sites of dolphins. Commercially prepared bacterial identification kits such as the API-20 E systems are usually used to identify enterobacteria. These identification kits are useful when human clinical samples are analysed but have limited value when samples known to contain many environmental species of vibrio are analysed.

This article highlights the necessity of using expanded biochemical identification methods to identify vibrio bacteria carefully recovered from the unbroken (normal), and broken (wounded) skin of dolphins as well as from coastal pen water. Using this approach, we have identified a vibrio bacteria specifically associated with the wound infections of dolphins 
as Vibrio damsela. This vibrio, a known pathogen of fish and warm blooded animals, is believed to be responsible for wound infections in dolphins.

\section{MATERIALS AND METHODS}

Sampling sites and sampling methods. Marine mammal sea pens at the Naval Ocean Systems Center, Hawaii Laboratory, were the locations for this study. Bottlenose dolphins Tursiops truncatus kept in these pens, especially 3 individuals with slow-healing skin lesions, clinically diagnosed as bacterial infections, were studied. These 3 dolphins were initially treated with $30 \mathrm{mg} \mathrm{kg}^{-1}$ daily of Tribrissen (trimethoprim/sul-

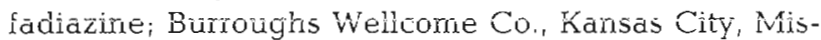
souri, USA) incorporated into their fish feed. To recover vibrio bacteria from pen waters, grab samples of waters were collected in sterile plastic bottles. To recover vibrios adhered to and established on healthy skin or in the skin wounds of dolphins, the skin sites were initially washed free of environmental water by scrubbing with betadine and alcohol. After drying, they were scraped with sterile cotton swabs to recover the skinassociated bacteria adhered to healthy or wounded skin. These swabs were immediately placed into Amies Transport Medium (Schroeder et al. 1985). All samples were transported to the laboratory in an iced chest and processed within 6 h of collection.

Analysis of samples. Thiosulfate-citrate-bile-salt (TCBS) agar medium (Difco Co., Detroit, Michigan, USA) was the selective medium used to recover vibrio bacteria from all samples. Water samples were processed using the membrane filtration method, while skin swabs were streaked directly onto TCBS agar. Target vibrio colonies on TCBS were either green (sucrose negative) or yellow (sucrose positive). These presumptive vibrio colonies were streaked for isolation on trypticase soy agar supplemented with $2 \%$ marine salts and subsequently characterized by selective biochemical tests. All diluents and biochemical tests were conducted using $2 \%$ marine salts (MacDonell et al. 1982). The API-20 E identification system (Analytab Products, Plainview, New York, USA), which relies on 26 tests, was used to initially characterize these presumptive vibrio isolates. During the initial phases of our study (1984), the API-20 E identification system was limited to speciating only 6 human pathogenic vibrios which were published in the API Analytical Profile Index manual. Since 1985, 3 additional human pathogenic vibrio species have been given API identification code numbers. Recognizing the limitation of the API-20 E system for identifying Vibrio spp. recovered from environmental sources, a more extensive identification system proposed by West \& Colwell (1984), which relies on 54 tests to identify 20 species of vibrio, was used in this study.

Antibiotic susceptibility assay. The antibiotic susceptibility pattern or 'antibiogram' (Eickhoff \& Ehret 1980) of the vibrios recovered in this study was determined using the single disk diffusion method of Bauer et al. (1966). Mueller-Hinton agar supplemented with $2 \%$ marine agar salts was used. Antibiotic disks were obtained from BBL (Cockeysville, Maryland, USA) and used to determine vibrio susceptibility: sulfadiazine $(1 \mu \mathrm{g})$, trimethoprim $(5 \mu \mathrm{g})$, trimethoprim $(1 \mu \mathrm{g}) / \mathrm{sul}$ famethoxazole $(24 \mu \mathrm{g})$, cefamandole $(30 \mu \mathrm{g})$, cefoxitin $(30 \mu \mathrm{g})$, cephalothin $(30 \mu \mathrm{g})$, penicillin $\mathrm{G}(10 \mathrm{units})$, ampicillin $(10 \mu \mathrm{g})$, carbenicillin $(100 \mu \mathrm{g})$, amikacin $(30 \mu \mathrm{g})$, gentamicin $(10 \mu \mathrm{g})$, kanamycin $(30 \mu \mathrm{g})$, neomycin (30 $\mu \mathrm{g}$ ) strepiomycin $(10 \mu \mathrm{g})$, erythromycin ( $15 \mu \mathrm{g}$ ), tetracycline $(30 \mu \mathrm{g})$, chloramphenicol $(30 \mu \mathrm{g})$. Vibriostatic agent 0/129 (2,4-diamino-6,7-disopropylpteridine) was obtained from BDA Chemicals (Poole, England) from which 10 and $150 \mu \mathrm{g}$ disks were prepared. The diameters of the inhibition zones surrounding each disk were measured to the nearest $\mathrm{mm}$ after $18 \mathrm{~h}$ of incubation at $37^{\circ} \mathrm{C}$. Bacterial isolates were characterized as resistant $(\mathrm{R})$, sensitive (S) or intermediate (I) according to the specifications for each disk provided by the manufacturer.

\section{RESULTS}

\section{Pre- and post-treatment of dolphins}

Before treating the dolphins, bacteria from skin lesions were recovered on TCBS agar, and biochemically characterized using only the API-20 E system. Most of the isolates could not be identified to species, but based on the growth characteristics of these bacteria on TCBS agar and their biochemical characterization, they were tentatively identified as Vibrio sp. (Table 1). These isolates were also determined to be sensitive to sulfadiazine and the dolphins were treated with Tribrissen (trimethoprim/sulfadiazine) for 10 to $96 \mathrm{~d}$. The 3 dolphins selected for this study (Table 1) were observed to have slow-healing wounds on the flipper (Tt 018M), fluke ( $\mathrm{Tt} 583 \mathrm{M}$ ), and melon ( $\mathrm{Tt}$ $659 \mathrm{~F}$ ). Tribrissen treatment resulted in curing one dolphin and in a marked improvement in the other two (Table 1).

\section{Identification of vibrios from coastal pen water}

A total of 33 water samples from 3 dolphin pens were initially enumerated on TCBS agar. The average concentration of presumptive vibrio bacteria in these water 
Table 1. Culture and sensitivity of bacteria recovered from skin lesions of 3 dolphins before treatment and response to antibiotic treatment

\begin{tabular}{|c|c|c|c|c|c|c|}
\hline \multirow{2}{*}{$\begin{array}{l}\text { Dolphin } \\
\text { ID no. }\end{array}$} & \multicolumn{2}{|c|}{ Untreated skin lesions } & \multicolumn{2}{|c|}{ Bacteria recovered from lesions } & \multirow{2}{*}{$\begin{array}{l}\text { Tribrissen } \\
\text { treatment } \\
\text { (total days) }\end{array}$} & \multirow[t]{2}{*}{ Results } \\
\hline & Type & Location & Genus & Reaction to sulfadiazine & & \\
\hline Tt 018M & Ulcer & Flipper & Vibrio & Sensitive & 96 & Cured \\
\hline Tt $583 \mathrm{M}$ & Ulcer & Fluke & Vibrio & Sensitive & 21 & Improved \\
\hline Tt $659 \mathrm{~F}$ & Abscess (lanced) & Melon & Vibrio & Sensitive & 10 & Improved \\
\hline
\end{tabular}

samples was 594 vibrios $100 \mathrm{ml}^{-1}$. Greater than $80 \%$ of the presumptive vibrio colonies on TCBS agar was yellow (sucrose positive), round and mucoid in appearance, while the remaining presumptive vibrio colonies were green (sucrose negative). Eight presumptive vibrio colonies (5 yellow, 3 green) recovered from sea pen water were selected for biochemical characterization using the API-20E system and the West \& Colwell scheme. Four of the yellow colonies were identified as Vibrio alginolyticus by both the API-20 E and the West \& Colwell scheme. A typical biochemical profile of one of these isolates is summarized in Table 2. The fifth yellow colony, which could not be identified by the API-20 E system, was identified as $V$. marinus by the West \& Colwell scheme. The 3 green colonies were also unidentifiable by the API-20 E system but were identified as $V$. vulnificus, $V$. nigripulchritudo, and $V$. splendidus II by the West \& Colwell scheme.

The antibiograms (antibiotic susceptibility patterns) of the 8 identified vibrio isolates from pen water are summarized in Table 3. All 8 vibrio isolates were sensitive to sulfadiazine, chloramphenicol, and the trimethoprim/sulfamethoxyzole mixture, while 6 were sensitive to vibriostatic agent $0 / 129$. The 8 vibrio isolates were resistant to penicillin; 7 were resistant to ampicillin, while 6 were resistant to cephalothin, carbenicillin, and streptomycin.

\section{Identification of vibrios from healthy skin}

The predominant vibrios recovered from 8 healthy (unbroken) skin sites from 4 different dolphins were isolated and biochemically characterized. Using the West \& Colwell scheme, 7 of the 8 isolates were identified as Vibrio marinus, while the 8th isolate was identified as a $V$. pelagius II. In comparison, the API-20 E system was not able to identify 6 of the 8 isolates and identified 2 of the isolates as $V$. alginolyticus (Table 2).

The antibiograms of the 8 identified vibrios are summarized in Table 4 . All 8 isolates were sensitive to vibriostatic agent $0 / 129$ and chloramphenicol, 7 were sensitive to sulfadiazine and the mixture of trimethop$\mathrm{rim} / \mathrm{sulfamethoxazole}$, while 6 were sensitive to cefamandole and tetracycline. All 8 isolates were resistant to penicillin and 5 were resistant to ampicillin and carbenicillin. Three were resistant to trimethoprim.

\section{Identification of vibrios from wounds}

The predominant vibrios recovered from 8 wound samples on 3 dolphins were isolated and biochemically characterized. None of these 8 isolates could be identified to species by the API-20 E system. Using the West \& Colwell scheme, 2 were identified as $V$. marinus, and 1 isolate each as $V$. harveyi and $V$. gazogenes.

The 4 remaining isolates were biochemically similar and could not be identified to species using the West \& Colwell scheme. These 4 unidentifiable isolates were recovered from the wounds of 2 dolphins ( $\mathrm{Tt} 018 \mathrm{M}, \mathrm{Tt}$ $583 \mathrm{M}$ ) on 4 different occasions and were never recovered from the pen water or the healthy skin of dolphins. The typical biochemical profiles (Table 2) of these 4 wound-associated vibrios were then compared with the biochemical profiles of vibrio species not included in the West \& Colwell scheme and found to match up with those of Vibrio damsela (Love et al. 1981, Morris et al. 1982, Grimes et al. 1984, Farmer et al. 1985). Characteristics of our isolates which matched up with those of $V$. damsela included positive reactions for urease, arginine dihydrolase, oxidase, glucose, nitrate reductase, and Voges-Proskauer, and negative reactions for indole, orinithine decarboxylase, citrate, lactose, mannitol, arabinose, and hydrogen sulfide. In addition, our isolates required sodium chloride for growth, grew at 37 but not $42^{\circ} \mathrm{C}$ and were sensitive to vibriostatic agent $0 / 129$. One difference was the lysine decarboxylase reaction for $V$. damsela which was reported to be a variable characteristic for $V$. damsela by Morris et al. (1982) and by Farmer et al. (1985) but to be negative by Love et al. (1981) and by Grimes et al. (1984). In support of our conclusion that the 4 wound isolates were $V$. damsela, the API-20 E system has 
Table 2. Biochemical identification of the predominant vibrio recovered from pen water, unbroken skin and wounds of dolphins

\begin{tabular}{|c|c|c|c|c|}
\hline Test & Seawater isolate & \multicolumn{2}{|c|}{ Unbroken skin isolates } & \multirow{4}{*}{$\begin{array}{l}\text { Wound isolate } \\
\text { Green } \\
6015004 \\
\text { V. damsela }\end{array}$} \\
\hline Colony color on TCBS & Yellow & Yellow & Green & \\
\hline API-20E Profile No. & 4146124 & 4046124 & 4000004 & \\
\hline API-20E identification & $V$ alginolyticus & V. alginolyticus & Unidentifiable & \\
\hline Cytochrome oxidase & + & + & + & + \\
\hline Nitrate reduction & + & + & + & + \\
\hline Hydrogen sulfide & - & - & - & - \\
\hline Swarming & + & - & - & - \\
\hline Motility & + & + & + & + \\
\hline $0 / 129$ sensitivity $10 \mu \mathrm{g}$ & - & + & - & + \\
\hline $150 \mu \mathrm{g}$ & + & + & + & + \\
\hline Luminescence & - & - & - & - \\
\hline Arginine dihydrolase & - & - & - & + \\
\hline Lysine decarboxylase & + & + & + & + \\
\hline Ornithine decarboxylase & + & - & - & - \\
\hline Growth at $37 / 42{ }^{\circ} \mathrm{C}$ & $+1-$ & $+1-$ & $+1-$ & $+1-$ \\
\hline \multirow{5}{*}{$\begin{array}{rr}\text { Growth at \% } \mathrm{NaCl} & 0 \\
& 3 \\
6 \\
8 \\
10\end{array}$} & - & - & - & - \\
\hline & + & + & + & + \\
\hline & + & + & + & - \\
\hline & + & - & - & - \\
\hline & + & - & - & - \\
\hline Voges-Proskauer & - & - & - & + \\
\hline Gas from glucose & - & - & - & - \\
\hline \multicolumn{5}{|l|}{ Fermentation of: } \\
\hline glucose & + & + & + & + \\
\hline mannitol & + & + & + & - \\
\hline sorbitol & - & - & - & - \\
\hline rhamnose & - & - & - & - \\
\hline melibiose & - & - & - & - \\
\hline amygdalin & - & - & - & - \\
\hline lactose & - & - & - & - \\
\hline L-arabinose & - & - & - & - \\
\hline m-inositol & - & - & - & - \\
\hline D-mannose & + & + & + & + \\
\hline sucrose & + & + & - & - \\
\hline \multicolumn{5}{|l|}{ Enzyme production: } \\
\hline ONPG & - & - & - & - \\
\hline TDA & - & - & - & - \\
\hline urease & - & - & - & + \\
\hline indole & + & + & - & - \\
\hline alginase & - & + & + & - \\
\hline amylase & + & + & + & + \\
\hline chitinase & + & + & - & - \\
\hline gelatin agar/gelatinase & $+1+$ & $+1+$ & $-1+$ & $-1-$ \\
\hline lipase & + & + & + & + \\
\hline \multicolumn{5}{|l|}{ Sole carbon source: } \\
\hline citrate & - & - & - & - \\
\hline gamma-aminobutyrate & + & - & - & \\
\hline cellobiose & + & - & - & - \\
\hline L-citrulline & + & + & - & - \\
\hline ethanol & + & + & - & - \\
\hline D-gluconate & + & + & + & - \\
\hline L-leucine & + & + & - & + \\
\hline sucrose & + & + & - & - \\
\hline D-xylose & - & - & - & - \\
\hline $\begin{array}{l}\text { Identification by West \& } \\
\text { Colwell scheme: }\end{array}$ & V. alginolyticus & $V$ marinus & $V$. marinus & Unidentifiable \\
\hline
\end{tabular}


Table 3. Antibiotic susceptibility patterns of vibrio bacteria recovered from seawater pens of dolphins. R: resistant; I: intermediate sensitivity; S: sensitive

\begin{tabular}{|c|c|c|c|c|c|c|c|c|c|}
\hline \multirow[t]{2}{*}{ Antibiotic } & \multirow{2}{*}{$\begin{array}{c}\text { Disk } \\
\text { potency } \\
\text { ( } \mu \mathrm{g} / \text { units) }\end{array}$} & \multicolumn{8}{|c|}{ Predominant vibrio recovered from sample numbers: } \\
\hline & & 1 & 2 & 3 & 4 & 5 & 6 & 7 & 8 \\
\hline \multicolumn{10}{|c|}{ A. Sulfonamides/trimethoprim } \\
\hline 1. Sulfadiazine & 1 & $\mathrm{~S}$ & $\mathrm{~S}$ & $\mathrm{~S}$ & $\mathrm{~S}$ & $\mathrm{~S}$ & $\mathrm{~S}$ & $\mathrm{~S}$ & $\mathrm{~S}$ \\
\hline 2. Trimethoprim & 5 & $\mathrm{~S}$ & I & $\mathrm{I}$ & $\mathrm{R}$ & I & $\mathrm{S}$ & $\mathrm{S}$ & $\mathrm{S}$ \\
\hline 3. Trimethoprim/ & 1 & & & & & & & & \\
\hline sulfamethoxazole & 24 & $\mathrm{~S}$ & $\mathrm{~S}$ & $S$ & $\mathrm{~S}$ & $\mathrm{~S}$ & $\mathrm{~S}$ & $S$ & $\mathrm{~S}$ \\
\hline \multicolumn{10}{|l|}{ B. Cephalosporins } \\
\hline 4. Cefamandole & 30 & $\mathrm{~s}$ & $\mathrm{~S}$ & $\mathrm{R}$ & $\mathrm{R}$ & I & I & $\mathrm{S}$ & $S$ \\
\hline 5. Cefoxitin & 30 & $\mathrm{~S}$ & $\mathrm{~S}$ & $\mathrm{~S}$ & $\mathrm{R}$ & $\mathrm{R}$ & $\mathrm{R}$ & $\mathrm{S}$ & S \\
\hline 6. Cephalothin & 30 & $\mathrm{R}$ & $\mathrm{S}$ & $\mathrm{R}$ & $\mathrm{R}$ & $\mathrm{R}$ & $\mathrm{R}$ & I & $\mathrm{R}$ \\
\hline \multicolumn{10}{|l|}{ C. Penicillins } \\
\hline 7. Penicillin G & 10 & $\mathrm{R}$ & $\mathrm{R}$ & $\mathrm{R}$ & $\mathrm{R}$ & $\mathrm{R}$ & $\mathrm{R}$ & $\mathrm{R}$ & $\mathrm{R}$ \\
\hline 8. Ampicillin & 10 & $\mathrm{R}$ & $\mathrm{S}$ & $\mathrm{R}$ & $\mathrm{R}$ & $\mathrm{R}$ & $\mathrm{R}$ & $\mathrm{R}$ & $\mathrm{R}$ \\
\hline 9. Carbenicillin & 100 & $\mathrm{R}$ & $\mathrm{S}$ & $\mathrm{R}$ & $\mathrm{R}$ & $\mathrm{R}$ & $\mathrm{R}$ & I & $\mathrm{R}$ \\
\hline \multicolumn{10}{|l|}{ D. Aminoglycosides } \\
\hline 10. Amikacin & 30 & I & I & $\mathrm{S}$ & $\mathrm{R}$ & $\mathrm{R}$ & $\mathrm{R}$ & I & $\mathrm{R}$ \\
\hline 11. Gentamicin & 10 & $S$ & $\mathrm{~S}$ & $\mathrm{~S}$ & I & $\mathrm{R}$ & $\mathrm{R}$ & $S$ & $\mathrm{R}$ \\
\hline 12. Kanamycin & 30 & $\mathrm{R}$ & I & I & $\mathrm{R}$ & $\mathrm{R}$ & $\mathrm{R}$ & $I$ & $\mathrm{R}$ \\
\hline 13. Neomycin & 30 & I & I & $\mathrm{S}$ & I & I & R & $\mathrm{S}$ & I \\
\hline 14. Streptomycin & 10 & I & $\mathrm{R}$ & I & $\mathrm{R}$ & $\mathrm{R}$ & R & $\mathrm{R}$ & $\mathrm{R}$ \\
\hline \multicolumn{10}{|l|}{ E. Macrolides } \\
\hline 15. Erythromycin & 15 & $\mathrm{~S}$ & $S$ & I & I & I & I & I & $S$ \\
\hline \multicolumn{10}{|l|}{ F. Broad spectrum } \\
\hline 16. Tetracycline & 30 & $\mathrm{~S}$ & I & I & $\mathrm{R}$ & $\mathrm{R}$ & $\mathrm{R}$ & $\mathrm{S}$ & $\mathrm{R}$ \\
\hline 17. Chloramphenicol & 30 & $\mathrm{~S}$ & $S$ & S & $\mathrm{S}$ & $\mathrm{S}$ & S & $\mathrm{S}$ & $S$ \\
\hline \multicolumn{10}{|l|}{ G. Vibristatic } \\
\hline 18. $0 / 129$ & 150 & $\mathrm{~S}$ & $\mathrm{~S}$ & $\mathrm{~S}$ & $\mathrm{R}$ & $\mathrm{S}$ & S & $\mathrm{S}$ & $\mathrm{R}$ \\
\hline
\end{tabular}

recently added $V$. damsela to its identification bank and now identifies the API-20 E profile number of our isolate $(6015004)$ as $V$. damsela.

The antibiograms of the 8 vibrios recovered from dolphin wounds are summarized in Table 5 . The 8 isolates were sensitive to vibriostatic agent $0 / 129$ and to the trimethoprim/sulfamethoxazole mixture; 7 were sensitive to gentamycin while 6 were sensitive to cefamandole, ampicillin, tetracycline, and chloramphenicol. All 8 isolates were resistant to penicillin and 6 were resistant to streptomycin. None of these 8 wound isolates were sensitive to sulfadiazine or trimethoprim, the antimicrobials used to treat the dolphins. Four were resistant to sulfadiazine, and 5 were resistant to trimethoprim. The remaining isolates were intermediate in their response to these 2 antibiotics.

\section{DISCUSSION}

Numerous species of vibrio multiply in natural marine water environments. A vibrio identification sys- tem such as the API-20 E system which utilizes 26 biochemical tests to identify only human pathogenic vibrio species has limited use in the identification of vibrios recovered from marine samples. The API-20 E system was designed to identify vibrio bacteria recovered from human clinical samples where vibrio species found in marine waters should not be present. When the API-20 E system is used to identify environmental isolates of vibrio, it tends to match up the unknown vibrio with the pathogenic vibrio in its reference bank and may incorrectly identify some closely related environmental species of vibrio as human pathogenic vibrios. A more extensive identification scheme, such as that proposed by West \& Colwell (1984) utilizing 54 biochemical tests to identify human pathogenic and environmental species of vibrio, is required to identify vibrios recovered from marine samples. Using this expanded system, the predominant vibrio in the marine mammal coastal pen water was identified as Vibrio alginolyticus, while the predominant vibrio recovered from the healthy skin of dolphins was $V$, marinus. The predominant vibrio recovered 
Table 4. Antibiotic susceptibility patterns of vibrio bacteria recovered from healthy skin of 4 dolphins. R: resistant; I: intermediate sensitivity; $\mathrm{S}$ : sensitive

\begin{tabular}{|c|c|c|c|c|c|c|c|c|c|}
\hline \multirow[t]{2}{*}{ Antibiotic } & \multirow{2}{*}{$\begin{array}{c}\text { Disk } \\
\text { potency } \\
\text { (ug/units) }\end{array}$} & \multicolumn{8}{|c|}{ Predominant vibrio recovered from sample numbers: } \\
\hline & & $\begin{array}{c}1 \\
(538 \mathrm{M})^{\circ}\end{array}$ & $\begin{array}{c}2 \\
(583 \mathrm{M})\end{array}$ & $\begin{array}{c}3 \\
(583 \mathrm{M})\end{array}$ & $\begin{array}{c}4 \\
(583 \mathrm{M})\end{array}$ & $\begin{array}{c}5 \\
(596 \mathrm{~F})\end{array}$ & $\begin{array}{c}6 \\
(659 F)\end{array}$ & $\begin{array}{c}7 \\
(596 \mathrm{~F})\end{array}$ & $\begin{array}{c}8 \\
(579 F)\end{array}$ \\
\hline \multicolumn{10}{|c|}{ A. Sulfonamides/trimethoprim } \\
\hline 1 Sulfadiazine & 1 & $\mathrm{~S}$ & $\mathrm{~S}$ & $\mathrm{~S}$ & $\mathrm{~S}$ & $\mathrm{~S}$ & $\mathrm{~S}$ & $\mathrm{~S}$ & I \\
\hline 2. Trimethoprim & 5 & $\mathrm{R}$ & I & $\mathrm{R}$ & $\mathrm{R}$ & $\mathrm{S}$ & $\mathrm{S}$ & I & I \\
\hline 3. Trimethoprim/ & 1 & & & & & & & & \\
\hline sulfamethoxazole & 24 & S & $\mathrm{S}$ & I & $\mathrm{S}$ & $\mathrm{S}$ & $\mathrm{S}$ & $\mathrm{S}$ & $\mathrm{S}$ \\
\hline \multicolumn{10}{|l|}{ B. Cephalosporins } \\
\hline 4. Cefamandole & 30 & $\mathrm{~S}$ & $S$ & $\mathrm{~S}$ & $S$ & $\mathrm{~S}$ & I & $\mathrm{S}$ & $\mathrm{R}$ \\
\hline 5. Cefoxitin & 30 & I & $S$ & $\mathrm{R}$ & $\mathrm{R}$ & $\mathrm{S}$ & $\mathrm{R}$ & I & $\mathrm{R}$ \\
\hline 6. Cephalothin & 30 & $\mathrm{~S}$ & $\mathrm{~S}$ & I & $\mathrm{R}$ & I & $\mathrm{R}$ & $\mathrm{R}$ & $\mathrm{R}$ \\
\hline \multicolumn{10}{|l|}{ C. Penicillins } \\
\hline 7. Pencillin Gi & 10 & $\mathrm{R}$ & $\mathrm{R}$ & $\mathrm{R}$ & $\mathrm{R}$ & $\mathrm{R}$ & $\mathrm{R}$ & $\mathrm{R}$ & $\mathrm{R}$ \\
\hline 8. Ampicillin & 10 & $\mathrm{~S}$ & $\mathrm{~S}$ & $\mathrm{~S}$ & $\mathrm{R}$ & $\mathrm{R}$ & $\mathrm{R}$ & $\mathrm{R}$ & $\mathrm{R}$ \\
\hline 9. Carbenicillin & 100 & $\mathrm{~S}$ & $\mathrm{~S}$ & I & $\mathrm{R}$ & $\mathrm{R}$ & $\mathrm{R}$ & $\mathrm{R}$ & $\mathrm{R}$ \\
\hline \multicolumn{10}{|l|}{ D. Aminoglycosides } \\
\hline 10. Amikacin & 30 & $\mathrm{~S}$ & $\mathrm{~S}$ & $\mathrm{R}$ & I & $\mathrm{S}$ & $\mathrm{R}$ & $\mathrm{S}$ & $\mathrm{R}$ \\
\hline 11. Gentamicin & 10 & $S$ & $\mathrm{~S}$ & I & s & $\mathrm{S}$ & I & $\mathrm{S}$ & I \\
\hline 12. Kanamycin & 30 & $\mathrm{~S}$ & $\mathrm{~S}$ & I & I & $\mathrm{S}$ & I & $\mathrm{S}$ & $\mathrm{R}$ \\
\hline 13. Neomycin & 30 & $\mathrm{~S}$ & $\mathrm{~S}$ & I & I & $S$ & I & $\mathrm{S}$ & $\mathrm{R}$ \\
\hline 14. Streptomycin & 10 & $\mathrm{~S}$ & I & $\mathrm{R}$ & I & I & $\mathrm{R}$ & I & $\mathrm{R}$ \\
\hline \multicolumn{10}{|l|}{ E. Macrolides } \\
\hline 15. Erythromycin & 15 & $\mathrm{~S}$ & I & $\mathrm{R}$ & $\mathrm{R}$ & $\mathrm{R}$ & I & I & $\mathrm{R}$ \\
\hline \multicolumn{10}{|l|}{ F. Broad spectrum } \\
\hline 16. Tetracycline & 30 & $\mathrm{~S}$ & $\mathrm{~S}$ & $\mathrm{~S}$ & $\mathrm{~S}$ & $\mathrm{~S}$ & I & $\mathrm{S}$ & I \\
\hline 17. Chloramphenicol & 30 & $\mathrm{~S}$ & $\mathrm{~S}$ & $\mathrm{~S}$ & $\mathrm{~S}$ & $\mathrm{~S}$ & $\mathrm{~S}$ & $\mathrm{~S}$ & $\mathrm{~S}$ \\
\hline \multicolumn{10}{|l|}{ G. Vibriostatic } \\
\hline 18. $0 / 129$ & 150 & $\mathrm{~S}$ & $\mathrm{~S}$ & $\mathrm{~S}$ & $\mathrm{~S}$ & $\mathrm{~S}$ & $\mathrm{~S}$ & $\mathrm{~S}$ & $\mathrm{~S}$ \\
\hline
\end{tabular}

from the slow-healing wounds of dolphins could not be identified using the West \& Colwell scheme, but was identified as $V$. damsela based on matching its biochemical profile to that of $V$. damsela as previously reported in the literature (Love et al. 1981, Morris et al. 1982, Grimes et al. 1984, Farmer et al. 1985).

This is the first report of Vibrio damsela infection of dolphins. These results support our original premise that some vibrio bacteria are pathogenic for dolphins. Buck \& Spotte (1986) recently reviewed the potential of vibrio bacteria infection for marine mammals. $V$. damsela has previously been recovered from 2 humans and an animal in Hawaii (Kreger 1984) indicating their presence in the marine waters of Hawaii. The pathogenicity of $V$. damsela has been reported to be due to its production of toxins (Kreger 1984, Kothary \& Kreger 1985). Kreger (1984) also reported that hemolytic strains of $V$. damsela are associated with pathogenic strains of $V$. damsela. The $V$. damsela isolated from the dolphins were hemolytic for sheep red blood cells.

The vibrios recovered and identified in this study were also characterized with regard to their antibiotic susceptibility patterns (antibiograms). Vibrios recovered from the water, as well as those from healthy skin sites and wounds of dolphin before treatment with Tribrissen (trimethoprim/sulfadiazine), were sensitive to trimethoprim and sulfadiazine. This information was essential in selecting the antimicrobial agent used to treat the dolphins. During treatment of the dolphins with Tribrissen, vibrios recovered from the wounds of the dolphins were no longer sensitive to trimethoprim and sulfadiazine. These wound-associated vibrios were determined to be resistant or had an intermediate reaction to trimethoprim and sulfadiazine. The determination that vibrio bacteria recovered from the wounds of dolphins were developing resistance to the antimicrobial used to treat the dolphins is additional evidence that these vibrios were multiplying in (infecting) the wound site. In contrast, vibrios recovered from healthy skin of dolphins or from the coastal pen waters were predominantly sensitive to trimethoprim and sulfadiazine. 
Table 5. Antibiotic susceptibility patterns of vibrio bacteria recovered from wounds of 3 dolphins. R: resistant; I: intermediate sensitivity; S: sensitive

\begin{tabular}{|c|c|c|c|c|c|c|c|c|c|}
\hline \multirow[t]{2}{*}{ Antibiotic } & \multirow{2}{*}{$\begin{array}{c}\text { Disk } \\
\text { potency } \\
\text { ( } \mu \text { g/units) }\end{array}$} & \multicolumn{8}{|c|}{ Predominant vibrio recovered from sample numbers: } \\
\hline & & $\begin{array}{c}1 \\
(018 M)^{*}\end{array}$ & $\begin{array}{c}2 \\
(018 \mathrm{M})\end{array}$ & $\begin{array}{c}3 \\
(583 \mathrm{M})\end{array}$ & $\begin{array}{c}4 \\
(583 \mathrm{M})\end{array}$ & $\begin{array}{c}5 \\
(583 \mathrm{M})\end{array}$ & $\begin{array}{c}6 \\
(583 \mathrm{M})\end{array}$ & $\begin{array}{c}7 \\
(659 F)\end{array}$ & $\begin{array}{c}8 \\
(659 F)\end{array}$ \\
\hline \multicolumn{10}{|c|}{ A. Sulfonamides/trimethoprim } \\
\hline 1. Sulfadiazine & 1 & I & I & I & $\mathrm{R}$ & I & $\mathrm{R}$ & $\mathrm{R}$ & $\mathrm{R}$ \\
\hline 2. Trimethoprim & 5 & $\mathrm{R}$ & I & I & $\mathrm{R}$ & $\mathrm{R}$ & $\mathrm{R}$ & I & $\mathrm{R}$ \\
\hline 3. Trimethoprim/ & 1 & & & & & & & & \\
\hline sulfamethoxazole & 24 & $\mathrm{~S}$ & $\mathrm{~S}$ & $\mathrm{~S}$ & $\mathrm{~S}$ & $S$ & $\mathrm{~s}$ & $\mathrm{~S}$ & $\mathrm{~S}$ \\
\hline \multicolumn{10}{|l|}{ B. Cephalosporins } \\
\hline 4. Cefamandole & 30 & $\mathrm{~S}$ & $\mathrm{~S}$ & $s$ & $\mathrm{~S}$ & $\mathrm{~S}$ & S & $\mathrm{R}$ & $\mathrm{R}$ \\
\hline 5. Cefoxitin & 30 & $S$ & $\mathrm{R}$ & $S$ & $\mathrm{~S}$ & I & I & $\mathrm{I}$ & $\mathrm{R}$ \\
\hline 6. Cephalothin & 30 & $\mathrm{~S}$ & I & $\mathrm{S}$ & $\mathrm{I}$ & I & I & $\mathrm{R}$ & $\mathrm{R}$ \\
\hline \multicolumn{10}{|l|}{ C. Penicillins } \\
\hline 7. Penicillin $G$ & 10 & $\mathrm{R}$ & $\mathrm{R}$ & $\mathrm{R}$ & $\mathrm{R}$ & $\mathrm{R}$ & $\mathrm{R}$ & $\mathrm{R}$ & $\mathrm{R}$ \\
\hline 8. Ampicillin & 10 & $\mathrm{~S}$ & S & $\mathrm{S}$ & 1 & $\mathrm{~S}$ & $\mathrm{~S}$ & $\mathrm{R}$ & $\mathrm{S}$ \\
\hline 9. Carbenicillin & 100 & $\mathrm{~S}$ & $\mathrm{~S}$ & $\mathrm{~S}$ & $\mathrm{R}$ & I & I & I & I \\
\hline \multicolumn{10}{|l|}{ D. Aminoglycosides } \\
\hline 10. Amikacin & 30 & $\mathrm{~S}$ & $\mathrm{I}$ & $\mathrm{S}$ & $\mathrm{R}$ & $S$ & $\mathrm{R}$ & S & $\mathrm{R}$ \\
\hline 11. Gentamicin & 10 & $\mathrm{~S}$ & $\mathrm{~S}$ & $\mathrm{~S}$ & $\mathrm{~S}$ & $\mathrm{~S}$ & $\mathrm{~S}$ & $\mathrm{~S}$ & $\mathrm{R}$ \\
\hline 12. Kanamycin & 30 & I & I & $\mathrm{R}$ & I & I & I & I & $\mathrm{R}$ \\
\hline 13. Neomycin & 30 & S & $\mathrm{S}$ & $S$ & I & $\mathrm{S}$ & I & I & $\mathrm{R}$ \\
\hline 14. Streptomycin & 10 & I & $\mathrm{R}$ & $\mathrm{R}$ & $\mathrm{R}$ & I & $\mathrm{R}$ & $\mathrm{R}$ & $\mathrm{R}$ \\
\hline \multicolumn{10}{|l|}{ E. Macrolides } \\
\hline 15. Erythromycin & 15 & $\mathrm{R}$ & I & I & $\mathrm{R}$ & I & I & $\mathrm{R}$ & $\mathrm{S}$ \\
\hline \multicolumn{10}{|l|}{ F. Broad spectrum } \\
\hline 16. Tetracycline & 30 & $\mathrm{~S}$ & $S$ & $\mathrm{~S}$ & I & $S$ & $\mathrm{~S}$ & $\mathrm{~S}$ & I \\
\hline 17. Chloramphenicol & 30 & $\mathrm{~S}$ & S & S & $\mathrm{S}$ & $\mathrm{S}$ & $S$ & I & $\mathrm{R}$ \\
\hline \multicolumn{10}{|l|}{ G. Vibriostatic } \\
\hline 18. $0 / 129$ & 150 & $\mathrm{~s}$ & $S$ & $S$ & $S$ & $\mathrm{~S}$ & $\mathrm{~S}$ & $\mathrm{~S}$ & $S$ \\
\hline
\end{tabular}

The results of this study support the microbiological principle that continued presence of antimicrobials will select for populations of bacterica which are resistant to the action of the antimicrobial agent. The study emphasizes the need to continually monitor the antibiotic susceptibility patterns of vibrio bacteria recovered from the wounds of treated marine mammals and demonstrates the essential role that a microbiological laboratory can play in the treatment of marine mammals.

Acknowlegdements. This research was supported by the Office of Naval Research, Department of the Navy, under the Molecular Biology Program directed by Dr Eli D. Schmell (Contract No. N 00014-84-K-0381). This paper is University of Hawaii Water Resources Research Center Contribution No. 195.

\section{LITERATURE CITED}

Bauer, A. W. Kirby, W. M. M., Sherris, J. C., Turck, M. (1966). Antibiotic susceptibility testing by a standardized single disk method. Am. J. Clin. pathol. 45: 493-496
Blake, P. A., Weaver, R. E. Hollis, D. G. (1980). Diseases of humans other than cholerae caused by vibrio. Ann. Rev. Microbiol. 34: 341-367

Bruce-Allen, L. J., Geraci, J. R. (1985). Wound healing in the bottlenose dolphin (Tursiops truncatus). Can. J. Fish. aquat. Sci. 42: 216-228

Buck, J. D., Spotte, S. (1986). The occurrence of potentially pathogenic vibrios in marine mammals. Marine Mammal Science 2 (4): 319-324

Di Salvo, L. H., Blecka, J., Zebal, R. (1978). Vibrio anguillarum and larval mortality in a California coastal shellfish hatchery. Appl. environ. Microbiol. 35: 219-221

Eickhoff, T H., Ehret, J. M. (1980). The use of antibiotics as tools in epidemiology and taxonomy. In: Lorian, $\mathrm{V}$ (ed.) Antibiotics in laboratory medicine. Williams \& Wilkins, Baltimore, Md, p. 490-505

Elston, R., Leibovitz, L., Relyea, D., Zatila, J. (1981). Diagnosis of vibriosis in a commercial oyster hatchery epizootic: diagnostic tools and management features. Aquaculture 24: $53-62$

Farmer IIl, J. J., Hickman-Brenner, F. W., Kelley, M. T. (1985). Vibrio. In: Lennette, E. H., Balows, A., Hausler, Jr, W J., Shadomy, H. J. (eds.) Manual of clinical microbiology, 4th edn. American Society for Microbiology, Washington, D. C., p. 282-301 
Geraci, J. R. (1981). Marine mammal care, 2nd edn. University of Guelph, Ontario

Grimes, D. J., Stemmler, J., Hadd, H., May, E. B., Maneval, D., Hetrick, F. M., Jones, R. T., Stoskopf, M., Colwell, R. R. (1984). Vibrio species associated with mortality of sharks held in captivity. Microb. Ecol. 10: 271-282

Howard, E. B., Britt, J. O., Matsumoto, G. K., Itahara, R. Nagano, C. (1983). Bacterial diseases. In: Howard, E. B. (ed.) Pathobiology of marine mammal diseases. CRC Press, Boca Raton, Fl., p. 69-118

Kothary, M. H., Kreger, A. S. (1985). Purification and characterization of an extracellular cytolysin produced by Vibrio damsela. Infect. Immun. 49: 25-31

Kreger, A. S. (1984). Cytolytic activity and virulence of Vibrio damsela. Infect. Immun. 44: 326-331

Lightner, D. V (1977). Vibrio disease. In: Disease diagnosis and control in North American marine aquaculture. Elsevier Scientific Publishing Co., New York, p. 19-26

Love, A., Teebheñ-Fisher, D., Hose, J. E., I:ärmer Mr, J. J., Fanning, G. R. (1981). Vibrio damsela, a marine bacterium, causes skin ulcers on the damselfish Chromis punctipinnis. Science 214: 1139-1140

MacDonell, M. T., Singleton, F. L., Hood, M. A. (1982). Diluent composition for use of API-20 E in characterizing marine and estuarine bacteria. Appl. environ. Microbiol. 44: 423-427
Mertz, P. A., Patti, J. M., Marcin, J. J., Marshall, D. A. (1987) Model for studying bacterial adherence to skin wounds. $J$. Clin. Microbiol. 25: 1601-1604

Morris, Jr, J. G., Wilson, R., Hollıs, D. G., Weaver, R. E., Miller, H. G., Tacket, C. O., Hickman, F. W., Blake, P. A. (1982). Illness caused by Vibrio damsela and Vibrio hollisae. Lancet i: $1294-1297$

Rubin, S. J., Tilton, R. C. (1975). Isolation of Vibrio alginolyticus from wound infections. J. Clin. Microbiol. 2: 556-558

Simpson, J. G., Cornell, L. H. (1983). Diseases associated with stranding and captivity. In: Howard, E. B. (ed.) Pathobiology of marine mammal diseases. CRC Press, Boca Raton, Fl., p. $26-64$

Schroeder, J. P., Wallace, J. G., Cates, M. B., Greco, S. B., Moore, P. W. B. (1985). An infection by Vibrio alginolyticus in an atlantic bottlenose dolphin housed in an open ocean pen. J. Wildl. Dis. 21: $437-438$

Tison, D. L., Nishibuchi, M., Greenwood, J. D., Seidler, R. J. (1982). Vibrio winiticuis Biogroup 2. new biogroup pathogenic for eels. Appl. environ. Microbiol 44: 640-646

West, P. A., Colwell, R. R. (1984). Identification and classification of Vibrionaceae-an overview. In: Colwell, R. R. (ed.) Vibrios in the environment. John Wiley \& Sons, New York, p. 285-363 